\title{
Exploring the influence of shelf-edge signage on consumer decision-making in Gauteng
}

\author{
Xania van der Merwe, Nadine C Sonnenberg, Daleen van der Merwe \\ \& Elizabeth Kempen
}

\begin{abstract}
Opsomming
Die kleinhandelindustrie wat toegespits is op die daarstelling van basiese lewensmiddele en kruideniersware het ' $n$ betekenisvolle invloed op die ontwikkellende Suid-Afrikaanse ekonomie. Talle aspekte wat verbruikersbesluitneming en -gedrag in hierdie kleinhandelomgewing beïnvloed is reeds oor die afgelope aantal jare ondersoek. 'n Aspek wat egter tot op hede min aandag geniet het in verbruikersnavorsing is die winkelrak-etikette wat in supermarkte en ander kruidenierswarewinkels aangewend word om prys en ander relevante produkinligting aan die verbruiker te kommunikeer. Alhoewel kleinhandelaars se gebruik en toepassing van winkelrak-etikette hoofsaaklik ingestel is op die oordrag van inligting, kan die vraag gestel word of die inligting wel van toepassing is in beperkte of nominale (gewoonte) verbruikersbesluitneming wat gepaard gaan met die aankoop van kruideniersware. Empiriese bevindinge toon dat hierdie tipes besluitneming geen of beperkte eksterne inligtingsoeke behels wat die inset wat winkelrak-etikette as 'n bron van eksterne inligting lewer in twyfel trek.
\end{abstract}

Ten einde lig te werp op hierdie area van onsekerheid het hierdie studie ten doel gehad om die rol van winkelrak-etikette as eksterne inligtingsbron in verbruikers se beperkte en nominale besluitnemingsprosesse tydens die keuse en aankoop van kruideniersware te verken en te beskryf. Daar is ook ondersoek ingestel na die probleme wat verbruikers ondervind in die gebruik van winkelrak-etikette en deelnemers aan die studie is gevra om aanbevelings te verskaf ter verbetering van die etikette. Hierdie inligting is relevant vir verskeie SuidAfrikaanse kettingwinkelgroepe wat tans die moontlikheid ondersoek om kapitaal te investeer in die opgradering van papierbasis etikette na elektroniese winkelrak-etikette.

Doelbewuste steekproefneming in die konteks-spesifieke omgewing van supermarkte is gebruik om verbruikers te werf van verskillende kulturele agtergronde en ouderdomme wat gebruik maak van winkelrak-etikettering tydens kruideniersware-inkopies. Werwing het plaasgevind in ' $n$ inkopiesentrum in die noorde van Johannesburg wat deur verbruikers van verskeie omliggende areas besoek word. Kwalitatiewe data-insamelingstegnieke wat semi-gestruktureerde onderhoude, projektiewe tegnieke en fokusgroepgesprekke insluit is gebruik om die verbruiker se perspektief te verstaan en te beskryf.

Die bevindinge van die studie toon dat winkelraketikette 'n betekenisvolle inset lewer as eksterne inligtingsbron tydens beperkte verbruikersbesluitneming. Inligting met betrekking tot die produk, prys en kleinhandelaangeleenthede (soos wanneer ' $n$ produk uit voorraad is of die datum waarop dit op die rak geplaas is) is veral van belang wanneer nuwe produkte of alternatiewe handelsmerke oorweeg word. Gedurende nominale of gewoonte besluitneming, soos in die geval van handelsmerkgetroue- of heraankope, word daar hoofsaaklik gesteun op interne bronne van inligting om aankoopbesluite te rig en word die waarde van winkelrak-etikette as minimaal geag.

Probleme wat ondervind is in die gebruik van winkelrak-etikette sluit die volgende in: verkeerde en onleesbare inligting, verkeerde posisionering van etikette en verbruikers se tydsbeperkinge. Hierdie aspekte blokkeer die potensïele waarde van winkelraketikette in verbruikers se soeke na eksterne inligting. Van besondere belang vir kleinhandelaars is verbruikers se reaksies op hierdie blokkeringsmeganismes wat in sommige gevalle daartoe lei dat hulle afstand doen van die aankoopbesluit en hul aankope by ' $n$ alternatiewe kleinhandelaar voortsit.

Uit die bogenoemde word dit duidelik dat meer beheer rondom winkelrak-etikettering uitgeoefen moet word. Die implementering van elektroniese winkelrak -etikettering kan in die opsig voordelig wees aangesien dit verhoogde data integriteit, meer akkurate inligting en permanente posisionering van etikette verseker. Deelnemers aan die studie het hierdie aspekte beklemtoon in hulle aanbevelings ter verbetering van winkelrak-etikettering. Hulle gevolgtrekking was dat die tipe inligting wat tans op die etikette verskyn van belang is, maar dat die inligtingswaarde verhoog kan word deur addisionele inligting by te voeg betreffende aspekte soos produkbestandele en voedingswaarde. Dit sou egter afhang van die kleinhandelaar se vermoë om akkurate beskrywings en korrekte plasing van die winkelrak-etikette te handhaaf. Meer omvattende navorsing met 'n groter steekproef sou egter nodig wees om die bevindinge van die studie te veralgemeen.

\section{- Ms X van der Merwe}

Master's degree student

Department of Consumer Science

North-West University, Potchefstroom

- Ms NC Sonnenberg

Department of Consumer Science

University of Pretoria

\section{- Dr D van der Merwe}

Department of Consumer Science

North-West University, Potchefstroom

\section{- Dr EL Kempen}

Department of Life and Consumer Sciences UNISA 


\section{INTRODUCTION}

The grocery industry, including all outlets focused on the reselling of groceries, toiletries and confectionery, has a vast influence on the developing South African economy. Within the South African context, these outlets have been estimated at a total of 69771 stores with a turnover of close to R64 729 million in 2002 (ACNielsen 2002:15). Hypermarkets and supermarkets single-handedly provided an income of approximately R25,3 million, most of which was generated in the Gauteng region (ACNielsen 2002:16). Considering the impact of this industry, it stands to reason that grocery shopping, and the retail environment in which it occurs, has been studied from several different perspectives. A recent study by Marx and Erasmus (2006), for example, focuses on the customer service attributes of supermarkets in the Tshwane Metropolis. An aspect that has received less attention, however, is the shelf-edge signage (also referred to as "shelf-edge labels" or "shelf talkers") used in the grocery retail environment.

Most grocery outlets make use of shelf-edge labels, primarily to communicate product and price information (Food Marketing Institute, 2001). Piemonte (2001) defines it as a printed card designed to be attached to the shelf, carrying a message about the product. Although grocery retailers' use and application of shelf-edge signage seem to revolve around the communication of information to the consumer (Manning et al, 2003; Nucifora, 1995; Piemonte, 2001), the question posed is whether consumers indeed use the information included on shelf-edge signage in their selection of grocery items. Empirical findings suggest that consumers either engage in nominal or limited decision-making during the acquisition of grocery items (Burgess, 1998:7). These types of decision-making involve low purchase involvement and low perceived risk, resulting in limited or no external search for information (Neal et al, 2006:63; Hawkins et al, 2007:510). The value of shelf-edge signage as an external source of information is therefore questioned.

Various studies conducted in more developed countries have in fact highlighted the significant impact of signage in retail stores and in particular the value it has as cues for information about products (Inman et al, 1990; Jansson et al, 2003). Inman et al (1990) conclude that some consumers would pay more attention to signage and cues surrounding the product than the product itself in their decision-making processes. Considering the fact that most decisionmaking processes occur within the store environment (Hui, 2004; Iris, 2002; Murphy, 2003), some might argue that the use of in-store information such as that provided by shelf-edge signage is inevitable. In applying a systems perspective (Whitchurch \& Constantine, 1993:335), shelf-edge labels could therefore be viewed as informational inputs in consumers' grocery decision-making processes. In this regard, organisations such as the Food Marketing Institute (2001) argue that the informational input of shelf-edge signage is not without problems. A typical example would include the occurrence of pricing discrepancies that may cause dissatisfaction among consumers.

The above research findings derived from countries other than South Africa provided initial ideas on the possible influences of shelf-edge signage on urban consumers' decision-making in South African grocery retail outlets. However, the divergent composition of the South African population and in particular the multiplicity of cultural groups relevant in this context would dictate a certain disparity with other consumer populations. To date no research in the South African grocery environment has been documented to underline the role of shelf-edge signage in consumers' decision-making processes.

The lack of empirical research in this regard is disconcerting, taking into account the effort, time and financial resources that South African retailers invest in providing these shelf-edge labels. In aligning for the future, the viability of introducing technological developments which require an even larger financial commitment, such as electronic shelf-edge labels, is also brought into question if shelf-edge signage does not succeed in being of value to the consumer (Food Marketing Institute, 2001; Fujitsu, 2005). Although shelf-edge signage benefits the grocery retailer with regard to certain aspects, such as not having to individually price products displayed on a shelf (Fox, 2002), an understanding of the consumer's point of view is necessary in order to justify future investment and to develop this type of signage to its full potential within the South African context.

\section{BACKGROUND}

\section{The grocery store environment}

Grocery shopping is a task performed by most if not all households on a daily, weekly and/or monthly basis. It is estimated that about three-quarters of an average household's income is spent in grocery stores (Urbany et al, 1996). Martins (2006) reports that in the South African context, households that fall within lower categories of living standards spend virtually their entire budget on basic necessities such as food. Apart from the amount of financial resources devoted to grocery shopping, findings of studies conducted in more developed countries leave little doubt that the physical store environment has a major impact on consumers' acquisition of grocery items. Research has indicated, for example, that $70 \%$ to $80 \%$ of all purchasing decisions occur within the store environment (Hui, 2004; Iris, 2002; Murphy, 2003). In this environment consumers have limited time available to spend on selecting each product (Kahn \& McAlister, 1997:117) and seldom perform extensive searches for information prior to the actual purchase being made (Hawkins et al, 2007:510). These circumstances typify very specific decision-making processes.

\section{Consumer decision-making in the grocery store environment}


Consumer decision-making is a popular research topic and various models have been developed to illustrate this process (Neal et al, 2006:33; Schiffman \& Kanuk, 2007:531). Traditional models of consumer decision-making tend to include five stages to describe the process, namely problem recognition, presearch stage, information search, evaluation of alternatives, choice and outcome evaluation (Erasmus et al, 2001). Some may also include aspects such as blocking mechanisms (Du Plessis \& Rousseau, 2007:263). Yet decisions can range from simple to highly complex and differ in terms of the amount of information that would be searched and alternatives that would be evaluated for a particular decision to be made (Cant et al, 2006:192).

Figure 1 includes a model presented by Hawkins et al (2007:511), which draws attention to the fact that the complexity and extent of decision-making processes may vary along with the purchase involvement. In general, consumer decisions can be divided into three categories: nominal or habitual, limited and extended decisions (Hawkins et al, 2007:511). Particularly relevant to the context of grocery shopping is decisions associated with a lower purchase involvement, namely nominal and limited decision-making (Neal et al, 2006:65; Hawkins et al, 2007:510).

As illustrated in Figure 1, both limited and extended decision-making include generic problem recognition, but these processes differ in terms of the information that is searched (Cant et al, 2006:200). Limited decision-making is based on internal information and only a limited amount of external information (Hawkins et al, 2007:513). Simple decision-making heuristics may be implemented (Cant et al, 2006:200) and few alternatives would be evaluated. After these steps have been taken the decision to purchase takes place, followed by post-purchase evaluation with no dissonance and limited evaluation (Hawkins et al, 2007:511).

Nominal decision-making, on the other hand, involves the least purchase involvement (Hawkins et al, 2007:511). As pointed out by Du Plessis and Rousseau (2007:267), when consumers are confident in attaining satisfaction based on previous experiences, they tend to be less involved with the decision. Typical

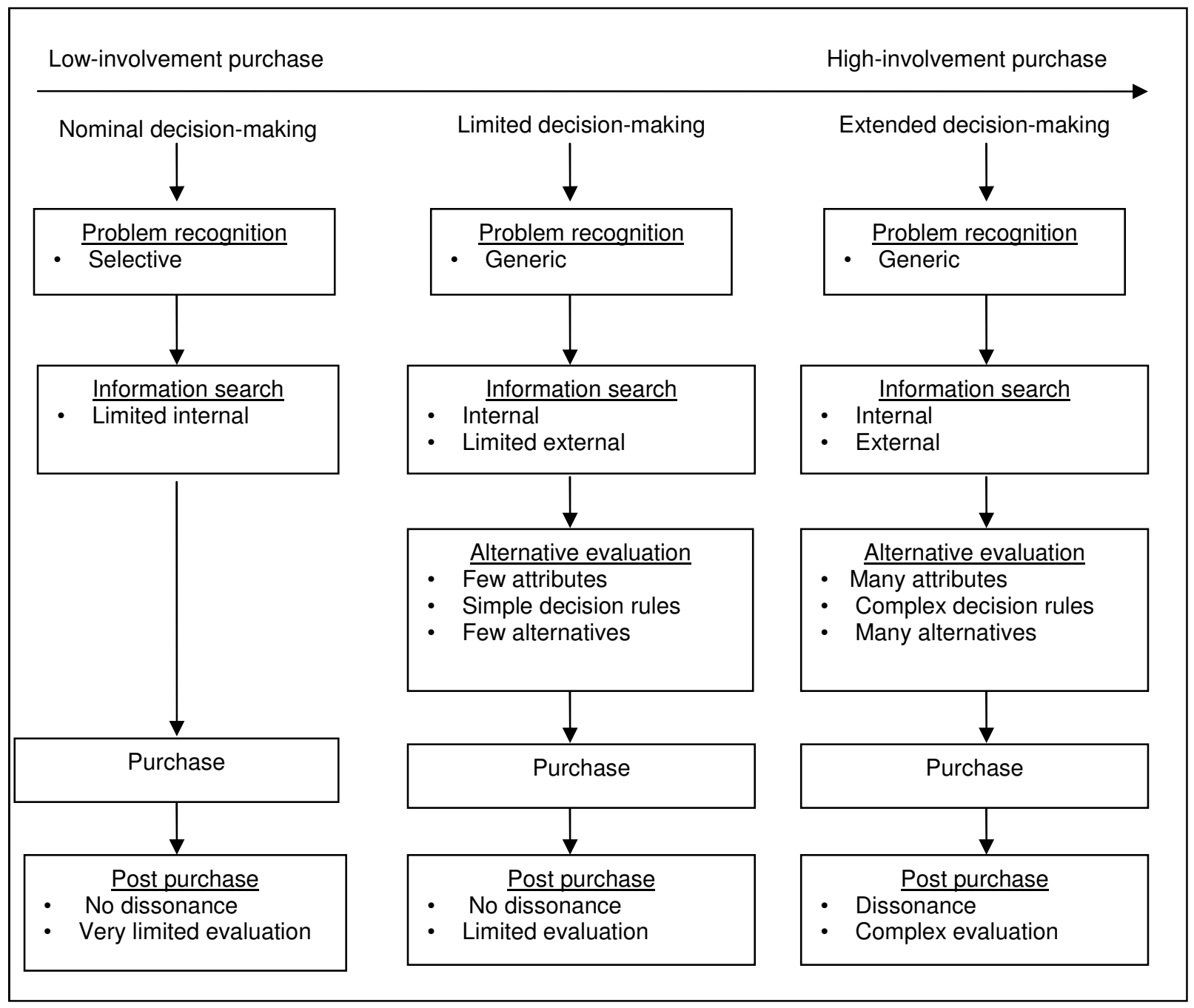

FIGURE 1: INVOLVEMENT AND TYPES OF DECISION-MAKING (Hawkins et al, 2007:511) 
examples would include brand-loyal and/or repeated purchases (Hawkins et al, 2007:512). In such cases, the consumer actively simplifies the decision to purchase (Neal et al, 2006:64). Problem recognition is selective (Hawkins et al, 2007:512) and information is mostly derived internally from memory (Cant et al, 2006:196), which may include brand beliefs and past experiences (Du Plessis \& Rousseau 2007:275). External information provided by shelf-edge signage may therefore not be of much value in these types of decisions. Alternatives are not evaluated and the product is simply purchased without much hesitation or deliberation about the matter (Hawkins et al, 2007:511). Similar to limited decision-making, post-purchase evaluation is associated with no dissonance, and the evaluation is very limited (Hawkins et al, 2007:511).

Nominal decision-making processes illustrate that consumers might under specific circumstances not engage in external information searching (Hawkins et al, 2007:512). It would be reasonable to conclude, however, that consumers do not always engage in this type of decision-making and that at some point in time they would need information on products in order to make optimal in-store purchasing decisions (Du Plessis \& Rousseau, 2007:267). Authors such as Vanhuele and Dreze (2000) further conclude that consumers are not always consciously aware of their continual search for information. In many cases the consumer would take note of information without deliberately searching for it.

Whether consumers engage in limited or nominal decision-making behaviour and consciously or subconsciously seek information, the outcome remains identical in that specific grocery items are acquired. The systems concept of "equifinality", as described by Whitchurch and Constantine (1993:334) and Spears (2004:43), characterises this situation in that the same output may be achieved although the input may differ in terms of the type of decision-making strategy applied along with the extent to which information is transformed. The following section provides more insight with regard to various other systems theory principles that can be applied to consumers' decisionmaking processes.

\section{Systems theory}

As explained by Whitchurch and Constantine (1993:330), one of the core assumptions of systems theory is that of self-reflexivity, which refers to the unique ability of human beings to make themselves and their own behaviour the object of examination. This would typically include consumer behaviour and consumer decision-making as illustrated in the model of Schiffman and Kanuk (2007:531). This model, shown in Figure 2, illustrates the decision-making process from a systems perspective and incorporates typical systems elements such as inputs, process (or transformation) and outputs.

Inputs refer to all external influences consumers are confronted with during decision-making processes, such as a company's marketing efforts focused on product, promotion, price and channels of distribution (Schiffman \& Kanuk, 2007:531). Within a grocery retail outlet, shelf-edge labels may be viewed as particularly useful methods of informing consumers about these marketing inputs. Apart from marketing inputs, Schiffman and Kanuk (2007:532) also acknowledge the fact that consumers' decision-making occurs within a specific socio-cultural environment. In more extended decision-making, information may be obtained, for example, from the family as well as informal and other non-commercial sources, and be incorporated into the decision-making process as an input.

The model (Figure 2) further clarifies consumer decision-making as a process whereby external influences such as marketing efforts and inputs from the sociocultural environment are transformed in consumers' recognition of their needs, their pre-purchase search for information and their evaluation of alternatives (Schiffman \& Kanuk, 2007:534). This process is then directed by the consumer's psychological field and includes aspects such as the individual's motivation, perception, learning, personality and attitudes (Schiffman \& Kanuk, 2007:532). Once the consumer has completed the decision-making process, experience is gained, which is then integrated back into the psychological field as indicated in Figure 2, and simultaneously leads to the accomplishment of certain outputs (Schiffman \& Kanuk, 2007:531).

Outputs refer to the results of the transformation process and represent the achievement of a system's goals (Gregoire \& Spears, 2007:2; Spears, 2004:41). Schiffman and Kanuk (2007:531) deem post-decision behaviour, such as the actual purchase (whether it be trial or repeat purchases) and post-purchase evaluation, as outputs of the decision-making process. As far as the post-purchase evaluation is concerned, Schiffman and Kanuk's (2007:531) model illustrates that it can influence consumers' future experience and psychological behaviour, which may be interpreted as feedback loops. As explained by Whitchurch and Constantine (1993:335), once established, a system maintains a certain pattern of behaviour (in this case decision-making) which is determined by such feedback loops.

In summary, Schiffman and Kanuk's (2007:531) model provides valuable insight into consumers' decisionmaking processes from a systems perspective. Perhaps not as clearly illustrated in this model is that the complexity and extent of decision-making processes may vary along with the purchase involvement and the amount of information searched, as highlighted in the model of Hawkins et al (2007:511). Thus, in combining these models a more comprehensive understanding of decision-making within a specific context and with regard to certain products can be gained. Authors such as Erasmus et al (2001) emphasise the importance of studying context- and product-specific consumer decision-making processes in order to contribute to theory building. With regard to grocery items, where most decisions to purchase occur within the store environment (Hui 2004; Iris 2002; Murphy, 2003), it may be argued that access to informational 


\section{External influences}

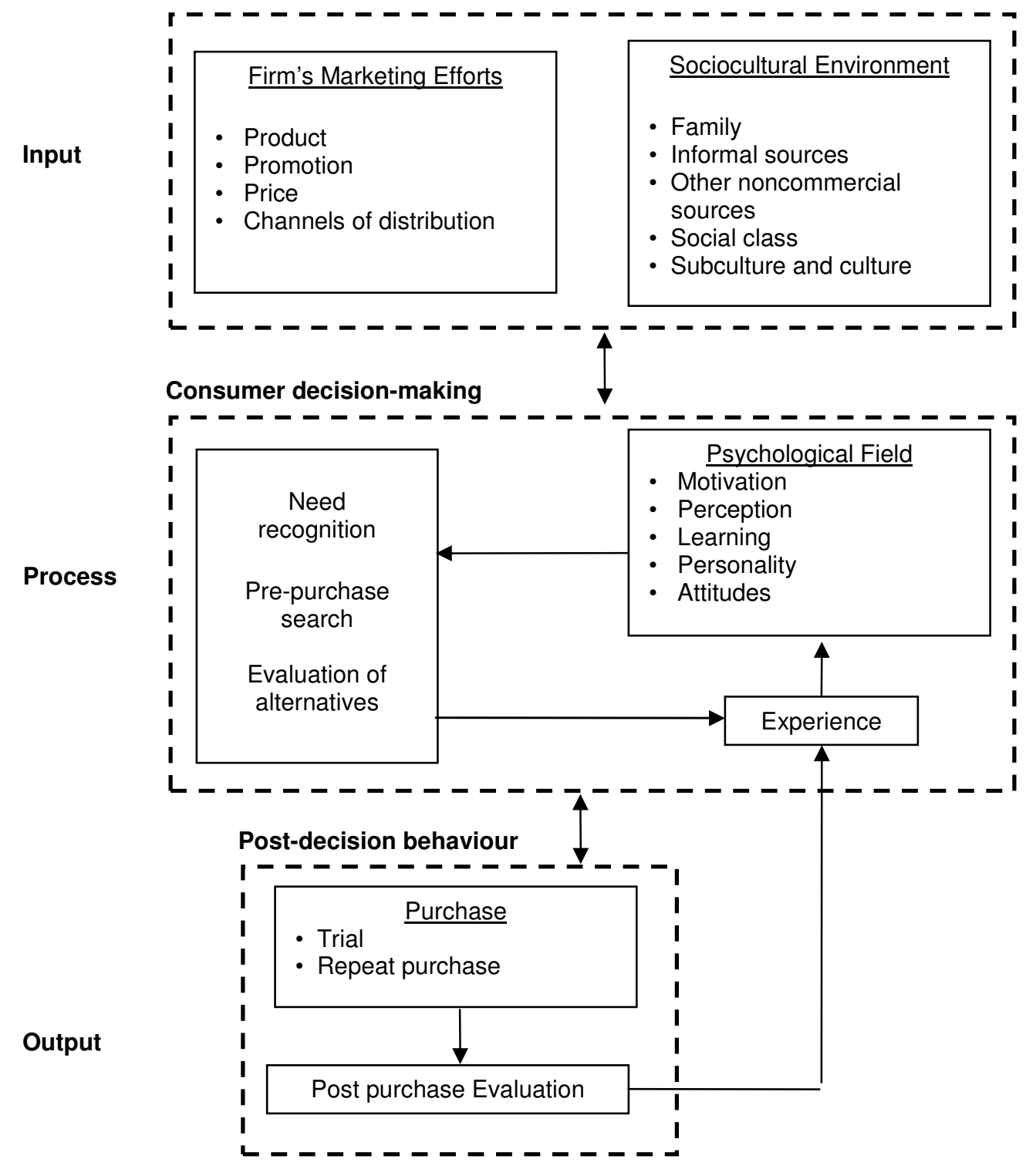

FIGURE 2:

\section{CONSUMER DECISION-MAKING FROM A SYSTEMS PERSPECTIVE (Schiffman \& Kanuk,} 2007:531)

inputs such as those provided by shelf-edge signage is important, as it could influence the way in which decision-making processes are transformed.

\section{The role of shelf-edge signage in consumer decision-making}

Consumers need information on products in order to make optimal in-store purchasing decisions (Du Plessis \& Rousseau, 2007:267). The main purpose and design of shelf-edge signage are focused on informing the consumer about aspects such as a product's size, name and unit price (Manning et al, 2003; Chandrasekharan, 2004; Competition Bureau, 2005). Yet the amount of attention paid to such information is decided by consumers during shopping (Bronneberg \& Vanhonacker, 1995) and is linked to the type of decision-making process (Hawkins et al, 2007:511), as indicated in previous discussions. In adopting a systems perspective, it may be argued that the role of shelf-edge signage would depend on the degree to which consumers allow information from external sources to enter their decisions (i.e. the permeability of boundaries that exist between their decisions and the context in which it occurs). This reflects the concept of "open systems", which theorists such as Spears (2004:41) and Whitchurch and Constantine (1993:335) describe in terms of the amount of interaction and information flow that occurs between a system and the environment in which it is embedded. 
Although consumers' decision-making processes might differ in terms of the significance attached to information derived from the external environment, most would view a product's price as essential information.

\section{Price information}

Various authors have indicated that price is a fundamental criterion during decision-making (Kahn \& McAlister, 1997:186; Hawkins et al, 2007:21). Many grocery retailers have replaced individual pricing of products with the use of shelf-edge signage that communicates the prices and unit prices of the products displayed on the relevant shelves. Not only is this method of pricing more cost-effective and less labourintensive than individual pricing (Fox, 2002), but the inclusion of unit pricing also enables the consumers to compare package size with price-related information, thus allowing for more informed economic decisions (Urbany et al, 1996; Miyazaki et al, 2000). This is of particular benefit to consumers who are sensitive to price or highly involved in the purchasing decision and who often make use of reference prices (Moon \& Russel, 2002). The reference price refers to the amount the consumer is expecting or willing to pay (Diamond \& Johnson, 1990) and is based on memory of prices previously paid (Dickson \& Sawyer, 1990; Vanhuele \& Dreze, 2000).

Shelf-edge signage thus enables consumers to compare store prices with reference prices and to determine the economic benefits of the purchase (Kelly et al, 2000). The disadvantages could outweigh the advantages, however, should the signage be incorrectly placed, removed or communicate incorrect information. These scenarios inhibit consumers' abilities to make optimal decisions, resulting in unsuccessful promotions and low decision satisfaction (Urbany et al, 1996).

\section{Problems related to the use of shelf-edge signage}

Although shelf-edge signage can be a valuable source of information during grocery shopping, problems regarding its use are not excluded. It would seem that most of these problems occur due to human error (Food Marketing Institute, 2001), with incorrect pricing identified as one of the main concerns in previous research (Bergen et al, 2004). Incorrect pricing occurs, for example, when prices are changed at checkout points, before they are updated on the shelf-edge labels (Competition Bureau, 2005). Clearly, such pricing discrepancies affect the retailer's profit (Food Marketing Institute, 2001). Moreover, it can also lead to consumer dissatisfaction. The prospect theory, originally established by Kahnaman and Tversky (1973) indicates that a small amount of negative feedback (caused by aspects such as incorrect shelf-edge signage) has a far greater impact on future shopping behaviour than a large amount of positive feedback. In aligning for the future, retailers have the option of investing in electronic shelf-edge labels, which provides solutions to many of these problems.

\section{Electronic shelf-edge labels (ESL)}

In recent years, technological developments have brought about the introduction of ESL (Food Marketing Institute, 2001). ESL technology provides several advantages. For example, human error is minimised by the fact that it enables immediate and accurate updates of information from a centralised data processing system throughout a retailer's entire stockholding and point-of-sale systems. Thus, prices are simultaneously changed on the shelf and at the pay point (Webb, 2002), thereby minimising incorrect pricing, enhancing internal control with less effort and ensuring data integrity between the point-of-sale controller and internal databases (Tagnetics, 2004). Since electronic equipment is secured to the shelf and does not need to be removed to be updated consumers will seldom be faced with the absence of shelf-edge information (Food Marketing Institute, 2001). ESL can further enhance the consumers' shopping experience by providing additional promotional information, comparisons among products, savings per product as well as reminders to buy related products (Webb, 2002).

Despite its success in the global market, ESL has to date not found widespread acceptance within the South African grocery retail sector (Fujitsu, 2005). This could be attributed to the fact that although ESL has become more affordable over the last few years (Fox, 2002), its initial implementation remains expensive (Webb, 2002). To justify the type of financial commitment that ESL would require, retailers are in need of a more in-depth understanding of consumers' use, expectations and problems with shelf-edge labels. To argue that shelf-edge signage is of informational value to consumers in their decision-making processes and simultaneously the cause of much dissatisfaction within the context of South African grocery retail outlets would remain mere speculation without research.

\section{RESEARCH OBJECTIVES}

To address the limitations in existing empirical research findings, the present study focused on exploring the role of shelf-edge signage in the decisionmaking processes that accompany urban consumers' acquisition of grocery products within a South African context. The first objective was to determine the informational input of shelf-edge signage in consumers' nominal and limited decision-making when selecting grocery items. Secondly, problems that consumers' may incur in their use of shelf-edge labels were investigated. Consumers' recommendations on how shelfedge signage could be improved to better facilitate their selection of grocery items were included as a third objective. In addressing these objectives, qualitative research methods were considered more appropriate and proved to be useful in obtaining rich descriptive data.

\section{RESEARCH DESIGN}

Limited empirical findings regarding the role of shelf- 
edge signage in consumers' grocery shopping behaviour inspired a qualitative naturalistic research design, during which data were collected in context-specific settings (Delport \& Fouché, 2005:262; Hoepfl, 1997) such as hypermarkets and supermarkets. Although these types of retail stores do not exceed other store types in number, their turnovers make them the most dominant grocery outlets in the South African context (ACNielsen, 2002:15) and therefore an important source of consumer information. The unfamiliar study terrain allowed for the application of a descriptive and exploratory research design with a phenomenological focus whereby data was collected with the intention of gaining an in-depth understanding of the consumer's point of view in an attempt to explicate the elements involved in shelf-edge signage behaviour (Babbie \& Mouton, 2007:80), The design also allows for the inclusion of a limited number of study participants (Maykut \& Morehouse, 1994:63). It should be noted, however, that sample limitation and the type of research design adopted in this study do not allow representativeness of the findings (Babbie \& Mouton, 2007:80).

\section{Sampling method}

Despite the diverse nature of the South African consumer population, most if not all South African consumers engage in some form of grocery shopping. Therefore, participant inclusion criteria were kept to a minimum with the intention of recruiting a heterogeneous sample of grocery shopping consumers that included males and females from different income groups and varying cultural backgrounds and who also ranged in age from their early 20 s to more than 50 years. However, certain aspects needed to be considered in terms of inclusion.

Although consumers residing in various geographical areas engage in grocery shopping, the focus in this particular study was on consumers in the Gauteng area. This area has been responsible for the largest contribution to the South African Grocery, Toiletry and Confectionery (GTC) industry (ACNielsen, 2002:16) and, as pointed out by Du Plessis and Rousseau (2007:47), reflects in one province the multicultural nature of South Africa. Furthermore, Kahn and McAlister (1997:117) suggest that consumers, due to their time constraints, would benefit more from information sources such as shelf-edge labels that facilitate quicker decision-making. In the light of the value of the consumer to the retail industry, it is worth determining the effect that shelf-edge signage has on the shopping behaviour of consumers residing in an area such as Johannesburg in Gauteng province, which is a shopping destination for consumers from various suburbs.

Two stores situated in a shopping complex in the northern parts of Johannesburg were selected as context-specific settings for the recruitment of participants and the collection of data. The particular shopping complex is considered a shopping destination for consumers from various suburbs in Johannesburg and surrounding areas such as Soweto, Roodepoort and Randburg. The specific stores that were selected form part of leading grocery retail chains that manage convenience stores as well as supermarkets and hypermarkets across South Africa. Observation of consumers in these grocery stores and the use of a purposive sampling method (Babbie \& Mouton, 2007:166) ensured that the recruitment of participants was appropriate (Barbour, 2001) and according to the purpose of the study (Mason, 1996:46). The sampling method permitted the recruitment of a heterogeneous sample of consumers (acknowledging the diverse nature of the South African population) and guaranteed that participants who were recruited for the study were exposed to shelf-edge signage and could therefore be included in discussions about the subject.

Consumers in the grocery stores were approached for voluntary interviews, after which they were invited to participate in focus group discussions. In-store recruitment continued until a sufficient number of participants agreed to take part in the study (Maykut \& Morehouse, 1994:62) and to ensure that data saturation in both in-store interviews and focus group discussions could be reached (Strydom \& Delport, 2005:328). Forty-five consumers were recruited and participated in the interviews to achieve data saturation.

\section{Data collection}

Three different data collection methods were used: semi-structured interviews, a projective technique and focus group discussions. All three methods were pilottested prior to the main study in an attempt to determine whether the data instruments were suitable for the purpose of the study and to familiarise the researcher with the research setting. For the researcher to gain some experience in dealing with each instrument and to find the optimal way to handle the respondents (Strydom \& Delport, 2005: 331; Strydom, 2005:211), the pilot test was executed in a convenient setting, using similar respondents to the main study (Strydom, 2005:210). In the light of the fact that in a qualitative study pilot testing of the instruments can be considered an informal way of establishing whether the instruments need to be modified to ensure quality data gathering (Strydom \& Delport, 2005:331), formal analysis of the findings is not presented.

Semi-structured interviews Permission was obtained from participants to record the interviews. Open -ended questions were used during the semistructured interviews as these types of questions projected the true opinions of the consumers (Greeff, 2005:297) and were beneficial in providing a detailed picture of the participants' views on shelf-edge signage. Participants' responses were probed through the use of an interview guide (Maykut \& Morehouse, 1994:45) that was based on the objectives of the study. Semi-structured interviews continued until data saturation was reached.

Focus group discussions in combination with a projective technique $A$ heterogeneous sample of participants was recruited from the semi-structured 
interviews to take part in the focus group discussions. A sentence completion projective technique was used as an introduction to the focus group discussions, as this technique is generally applied to reveal participants' unprompted feelings, ideas and subjective opinions (Donoghue, 2000; Du Plessis \& Rousseau, 2007:27). During this exercise, scenarios of grocery shopping situations were given to the participants, who were asked to complete a number of incomplete scenarios involving the use of shelf-edge signage with the first word or phrase that came to mind. The completed sentences served as a guideline for directing the focus group discussions.

Based on the experience gained in this particular study, it is advised that the projective technique be used in conjunction with other data collection methods and not as a single means of obtaining qualitative data. Participants were inclined to complete sentences with short phrases which provided limited clarity on their ideas and opinions regarding shelf-edge signage. Although no new or additional insights were derived from the technique, the written statements did in fact underpin the most essential and basic ideas communicated in the focus group discussions and interviews. The purpose of triangulation was therefore served. What proved to be particularly beneficial for the purposes of this study is the use of this exercise as a basis from which the focus group discussions could be initiated.

Focus group discussions, as pointed out by Stewart and Shamdasani (1990:15), offer various advantages that are considered relevant in this particular study. Apart from being an affordable data collection tool, focus group discussions allow participants to probe the opinions of others, thereby stimulating more indepth discussions and the collection of rich descriptive data. Yet it is argued that proper preparation and training of the facilitator during the pilot study contributed to the success of applying this technique. Furthermore, the sequence in which the data collection methods were applied proved to be particularly useful in preparing participants for the focus group discussions.

Twenty-two of the initial 45 participants interviewed agreed to participate in the focus group discussions and projective exercises. During the interviews participants' initial ideas surrounding the use of shelf-edge signage were probed, which they could further consider before exposure to the other techniques. Five focus group sessions were held involving both males and females from different cultural and socioeconomic backgrounds. Groups were limited to four or five participants, thereby ensuring that each was afforded the opportunity of sharing his/her opinion and to effectively participate in the discussion.

During focus group discussions participants can stimulate the ideas of others (Stewart \& Shamdasani, 1990:15) and therefore need to have a comfortable atmosphere. Careful consideration was paid to the selection of a venue for these discussions, as they required a comfortable atmosphere conducive to the sharing of opinions and open communication. Restaurants with meeting/conference facilities, conveniently located in close proximity of the retail outlets where interviews were conducted, were used for these purposes. Participants were not financially compensated for participation, but refreshments were served, which were welcomed by many in their normal shopping routine.

Permission was obtained from participants to record the discussions. Annotations made during the session were discussed with participants afterwards, thereby increasing the credibility of the data through member checks (Maykut \& Morehouse, 1994:147). Field notes and audio recordings of interviews and focus group discussions as well as the completed projective technique sentences serve as the basis for data analysis.

\section{Data analysis}

The qualitative nature of the study resulted in a large amount of raw data, which needed to be analysed in a manner that would conserve the rich and descriptive value of the data. Accordingly, all recordings of focus group discussions and in-store interviews were first transcribed verbatim, to make certain the transcriptions remained true to the phenomenological nature of the data. All comments were listed and the statements of participants who communicated in languages other than English were carefully translated to ensure that the original meaning would be preserved. The transcripts became the data used for analysis, which enabled the researcher to refer to the data repeatedly (Maykut \& Morehouse, 1994:134).

Content analysis was the preferred method to access the text and determine the meaning of shelf-edge signage to the consumer (Henning et al, 2004:102). An open coding system was applied. Open coding allows the researcher to break down the data in discrete parts, closely examine and label units of meaning or text that has relevance to the purpose of the study (De Vos, 2005:341; Auerbach \& Silverstein, 2003:37; Henning et al, 2004:102). During coding, the researchers continuously suspended prior knowledge on the subject in order to enter the participants' phenomenological world, thereby allowing the researchers to understand their ideas, perceptions and experiences, as suggested by Hayes (2000:189). All of the available data was used, and at this stage the researchers referred to the study's objectives to assist in the analysis.

Codes (also referred to as concepts) were then grouped into categories that identified particular phenomena in the data. The researcher named inductively. This process automatically began to indicate possible themes arising from the data (De Vos, 2005:341; Henning et al, 2004:106). These themes were identified as ideas or topics, which appeared repeatedly throughout the transcripts. For the purposes of analysis, each theme was colour-coded. The themes were listed in tables accompanied by verbatim quotations from the interviews and focus group discussions as well as statements derived from the pro- 
jective techniques. Where possible, the identified themes were supported by existing literature and reviewed by a team of experienced consumer researchers. No information was ignored and all records, including field notes and transcripts, were kept for the purposes of conformability.

\section{Trustworthiness}

Strategies to ensure the trustworthiness of the data and results were derived from the model of Lincoln and Guba (1985:385), the principles of Krefting (1991), as well as some of the strategies described by authors such as Maykut and Morehouse (1994:147), Mays and Pope, (2000:4) and Babbie and Mouton (2007:276). These strategies were focused on ensuring credibility, transferability, dependability and conformability of the study. Criteria specific to each of these aspects were applied.

Field experience is an important criterion for the credibility of the study. In this regard, a pilot study prior to the onset of the main study was performed to explore the research setting, verify the effectiveness of the data collection methods, and train the researcher on the research methods and the interviewing skills required. This included spending sufficient time with participants to allow complete verbalisation of their views. Triangulation, another criterion for credibility, was accomplished through the use of three different data collection methods. Forty-five semi-structured instore interviews, five focus group discussions and 22 projective technique exercises were completed to find support for the concepts and themes identified and to ensure that data saturation was achieved. Additional criteria for credibility included reflexibility (field notes were made during data-collection sessions and subjected to analysis), peer debriefing (analysis of raw data by a co-researcher) and member checks (field notes were discussed with participants to ensure the notes corresponded with their opinions). A control of literature on decision-making was also performed to ensure credibility of findings.

A detailed description of the research methodology allowed for the transferability and dependability of the study. For transferability purposes, specific details pertaining to the selection of the sample and the purposive sampling method were highlighted. The use of various data collection methods and, more specifically, consistency in the application of these data capturing methods (such as the use of the same question guide for each participant) contributed to the dependability of the study. In addition to the above, peer examination and confirmation by experienced researchers of the themes and concepts identified in the data analysis further ensured that the criteria for dependability were met. Finally, all records and transcripts were kept and audited by the research supervisors for the purposes of conformability.

\section{FINDINGS AND INTERPRETATION}

Literature clarifies the fact that consumers engage in either nominal or limited decision-making during grocery shopping (Burgess, 1998:7). The findings of this study confirm that these decision-making processes mostly occur within the store environment, as described by authors such as Iris (2002), Murphy (2003) and Hui (2004). It was further established that the informational value of shelf-edge signage differs in terms of the types of decision-making processes that consumers engage in when acquiring grocery products.

\section{Informational value of shelf-edge signage in limited decision-making}

As pointed out by Hawkins et al (2007:511), consumers use internal information, as well as a limited amount of external information, during limited decision -making. A prominent theme that emerged from the data analysis is that shelf-edge labels are particularly useful as external sources of information during these decision-making processes. This is reflected in statements such as "...it provides information on which decisions regarding purchases can be made". This theme was addressed through the concepts of product -, price- and retail-related information.

Product-related information Information included on shelf-edge signage regarding products is sought by consumers under specific circumstances such as when they are interested in switching brands ("It helps me decide what to buy. In fact, I have just switched to this product") or when they are interested in trying new products ("I also like new stuff. Then you pay more attention to the shelf-edge label"). Overall, this type of information becomes increasingly important when participants know little about the product ("...when you know little about a product, you would look at the shelf -edge label").

Price-related information Information pertaining to price on shelf-edge signage was found to be key in the evaluation of product alternatives and was used by participants to identify the price of the products ("...to identify the product and the price"), to determine affordability ("I look at how much it costs and whether I can afford it") and to obtain the cheapest or best price ("well mostly for price, to get the cheapest option" and "to make sure that I get the best price or to get the best option"). Following the implementation of barcodes, individual pricing of products declined (Food marketing industry, 2001), and shelf-edge labels became the primary source of price information. In this regard, participants were of the opinion that prices indicated on shelf-edge signage were more convenient and easier to locate than individual prices ("...it is convenient to find the price there"; "...it is easier to locate than individual prices"). Apart from the above, shelf-edge labels also facilitate the comparison of prices among competing brands ("...for the price and to compare it to another brand"; "...when you have a really competing brand like tea. There are five teas, they are all imported and they all seem the same, so you look at the price on the shelf") as well as stores ("...to see how much the product costs and to compare it to other stores"). 
Unit pricing seemed to be of particular value to participants ("I like it if they break it down and give a unit price so that you can compare apples with apples") and was instrumental in establishing price references ("I use it for price reference"). Participants also indicated that they compare prices on shelf-edge signage to prices at the pay points ("I also check when it is scanned. I check if it is right. I memorise the price on the shelf and I know exactly how much it costs when I get to the till"). Such reactions could be related to the frequent occurrence of pricing discrepancies (Competition Bureau, 2005). This emphasises the importance of internal control by the retailers to ensure that accurate pricing is maintained on shelf-edge labels in order to keep their customers satisfied.

Retail-related information This type of information provided in the form of shelf-edge signage, such as the date the product was placed on the shelf, was also found to be important, especially with regard to perishable products ("... when they put it on the shelf and how long it has been on the shelf"; "... with perishable products you need a shelf life"). Tsiros and Heilman (2004) explain that when consumers are deciding on the purchasing of perishable products such as fruit, meat, confectionery or dairy products, freshness is one of the most important considerations. Participants agreed that by indicating on the shelf-edge signage the date when the product was placed on the shelf, their task is simplified since the information they need is at hand and they do not waste time in searching for it.

Participants have also grown accustomed to retailers' use of "out of stock" indicators and argue that if the grocery outlets indicate, through the use of shelf-edge signage, that a product is out of stock, it saves them time in searching for the product ("They would have those labels saying temporarily out of stock, then you know it is out of stock and you can stop looking"; "Temporary out of stock labels help a lot, it saves you time"). Based on the opinions of the participants, this strategy is successful and in fact now preferred by many ("I prefer it. It irritates me more to look for the product with the hope that it is packed incorrectly" and "Such labels are very helpful, then you know they still sell it, but the stock on the floor and in the storeroom is sold out"). These aspects demonstrate the value of shelf-edge signage in grocery consumers' limited decision-making processes and the accompanying search for external information.

\section{Nominal decision-making eliminating the use of shelf-edge signage}

Consumers can also engage in nominal decisionmaking during grocery shopping (Neal et al, 2006:64). During nominal decision-making, consumers make use of internal information and do not search for external information (Hawkins et al, 2007:512). This was confirmed in that shelf-edge signage was not used by consumers who engaged in typical nominal decisionmaking processes associated with repeat purchases ('Well you won't use it when you buy the same thing all the time") and brand-loyal purchases ("When you are a regular brand buyer you don't check it" and "I am brand loyal, I don't care about the label").

Nominal decision-making is characterised by low purchase involvement (Hawkins et al, 2007:512), which may involve familiarity with the product ("...if I know the product I would just grab and go") and renders the value of shelf-edge signage as an external source of information inconsequential ("When I know what I want to buy I do not look at the shelf-edge labels"). According to Du Plessis and Rousseau (2007:273), nominal decision-making can also encompass low price involvement, which surfaced in statements such as "she does not look how much it costs, she just throws it into the basket". These statements illustrate circumstances under which shelf-edge signage is of little value. Yet participants also explained that in some instances they want to make use of shelf-edge signage but cannot do so as a result various problems. These problems in essence represent blocking mechanisms that inhibit the use of shelf-edge signage.

\section{Blocking mechanisms that inhibit the use of shelf- edge signage}

Although many decision-making models do not include blocking mechanisms, authors such as $\mathrm{Du}$ Plessis and Rousseau (2007:263) recognise the occurrence of such mechanisms that influence the search and processing of information and describe them as obstacles encountered in the decision-making process. The present study indicated that participants were confronted with such blocking mechanisms, which included the following: incorrect information, incorrect positioning, eligible shelf-edge signage and time.

Incorrect information Inaccurate descriptions prevent consumers from using shelf-edge signage as external sources of information. This is illustrated in the following comments: "I don't use it at all, what is the use? It is always wrong" and "I often find that the labels are wrong". Consumers find price discrepancies particularly frustrating ("There are times when the shelf-edge signage does not correspond with what is charged at the till and that is very frustrating").

Incorrect positioning Erroneous placement or positioning was another blocking mechanism found to inhibit the use of shelf-edge signage. This occurs when the information communicated on the shelf-edge sign is not relevant or does not correlate with the products displayed on the shelf. A participant stated that "...sometimes they are mixed up, and I will look and I will take the product and when I get to the till, it is not what is on the shelf". In some instances, participants encountered difficulty in locating the relevant signage ("I can't find them") and the method of attaching the labels to the shelves was also criticised ("The way in which they attach the labels is not always effective - it falls off"). Yet another complaint revolved around the fact that certain retailers place too many shelf-edge labels on a particular shelf ("There are too many labels on the shelf, and consumers get confused with the products' codes"). To prevent this confusion some 
grocery outlets make use of product pointers on the shelf-edge label to indicate the position of the relevant product that is being referred to on the label. Yet when either the product or the shelf-edge label is incorrectly placed, these pointers can also create confusion and frustration ("Sometimes the arrows are not correct" and "The arrows are never in the right direction").

Illegible shelf-edge signage Shelf-edge signage that could not be read was another cause of discontent among participants reflected in statements, such as "it would be nice if you could read them". Participants commented that they were in many cases unable to read the information on the shelf-edge signs due to the small print ("It is so small. I have to use my reading glasses"). In addition, participants highlighted the fact that shelf-edge signage is not durable and do not withstand conditions in grocery stores ("When the labels get wet or damaged, you cannot read them").

Time constraints Consumers' time is often limited during grocery shopping (Kahn \& McAlister, 1997:117) and it therefore came as no surprise that some participants indicated that time constraints also served as blocking mechanisms in their use of shelf-edge signage. Participants indicated that consumers would not use shelf-edge signage when "...they don't have time to read, in other words, they are in a hurry" and that "...their time for shopping is limited and they have to search for the shelf-edge label". These comments emphasise the importance of incorporating into retail outlets shelf-edge signage that is clearly legible and easy to find. Retailers have no control over consumers' time constraints, but by presenting them with external information that is easy to find and read, the search for information may be perceived as less timeconsuming and the likelihood of their using the information is increased.

\section{Reactions to blocking mechanisms}

Participants' responses and reactions to blocking mechanisms that inhibit the use of shelf-edge signage varied from no significant response to more severe reactions such as a decision not to purchase and leaving the retail outlet and/or their patronage of another store. Statements such as "Many consumers would not complain. They are not going to bother" and "The problem is not that big. I still like the store" indicate that such blocking mechanisms may have no significant impact on consumers' shopping behaviour. Others would simply ask for assistance, as reflected in the following comment: "I would just ask someone if there is no price indication on it".

Yet to some people these blocking mechanisms become an immense source of frustration, forcing them to complain ("I always complain. It happens so often and that is annoying"; "I complain every time. It is very irritating"), abandoning the product and relinquishing the purchase intention ("I have watched consumers and if there is no price, they don't buy it, then the product ages on the shelf") and, in extreme cases, departing from the retail outlet and patronising an alternative outlet ("I hate it. I would go to another store";
"It gets to a point where I would go to a place where they do have proper signage. I'll go to another shop."). Fifteen of the 45 participants interviewed indicated that their reaction would include leaving the store and going to another. It stands to reason that within the competitive South African grocery environment, no retailer can afford losing clientele in such a manner.

Clearly illustrated in the above is that retailers need to be cognisant of the possible implications of shelf-edge signage that does not comply with standards set by consumers in this regard. Many of these situations are brought about by human error, and therefore the retailer can do much to improve the use and informational value of such signage. This is also reflected in the participants' suggestions for improving shelf-edge signage.

\section{Suggestions for improving shelf-edge signage}

Participants agreed that shelf-edge signage should include standard information pertaining to the product and its price ("...the price should stand out, and then, which product it is"), as well as barcodes ("... you often have to look at the barcode"). Most grocery outlets do include this information on their shelf-edge signage. However, not all grocery outlets include unit prices and the date of shelf placement on their signage. Participants emphasised the importance of such information and recommended that retailers should consider including these aspects ("they should look at adding the unit price" and "...the date on which the product was placed on the shelf"). Participants emphasised that information such as unit prices enables them to effectively compare products ("I find it important to make comparisons").

Apart from the above, participants also recommended that retailers should include other relevant information, such as product ingredients, calories and nutritional information ("I think they should specifically warn if there are a lot of additives, especially things like MSG or allergens"; "...add some nutritional information" and "with foods, how much calories"). As pointed out by Higgensom et al (2002), consumers tend to be more health-conscious and therefore more aware of product ingredients and nutritional information. Some participants opposed the idea based on blocking mechanisms such as incorrect information and positioning ("It holds too many dangers. The labels are so often wrong. Can you imagine if you read the incorrect label"). In this regard, participants emphasised that shelf-edge signage should be clear and legible ("...they are very unclear; you need to be able to read it"), accurately describing the product ("...they have to describe the products better") and positioned correctly ("...the correct labels have to stand on the right places").

The above findings illustrate that shelf-edge labels involve several complexities, many of which retailers can benefit from if incorporated into an effective strategy to influence consumers' shopping behaviour within a grocery store environment. However, due to the limited sample and exploratory nature of the study, 
more research would be needed in order to do so. Accordingly, the findings of the study are incorporated into a conceptual framework that is based on a systems approach and that may serve as a platform for embarking on future studies on shelf-edge labels.

\section{PROPOSED CONCEPTUAL FRAMEWORK FOR FUTURE STUDIES}

Although this study was primarily concerned with consumers' use of shelf-edge signage as an informational input during in-store decision-making processes, systems theory postulates that a system should be understood in its totality (Whitchurch \& Constantine,
1993:335). Consequently, Figure 3 represents a conceptual frame that depicts all the stages of the consumer decision-making process, as opposed to only reflecting the information search phase and the role of shelf-edge labels as an input in consumers' search for information. The framework represents a combination of a model of different types of decision-making (Hawkins et al, 2007:511) and a model on general decision-making from a systems perspective (Schiffman \& Kanuk, 2007:531). These have been adapted to incorporate the findings of this study. It should be noted that the conceptual frame illustrates consumer decision-making as a system embedded within the context of a larger supra system, which in this case refers to the grocery store environment. In keeping with the model proposed by Schiffman and

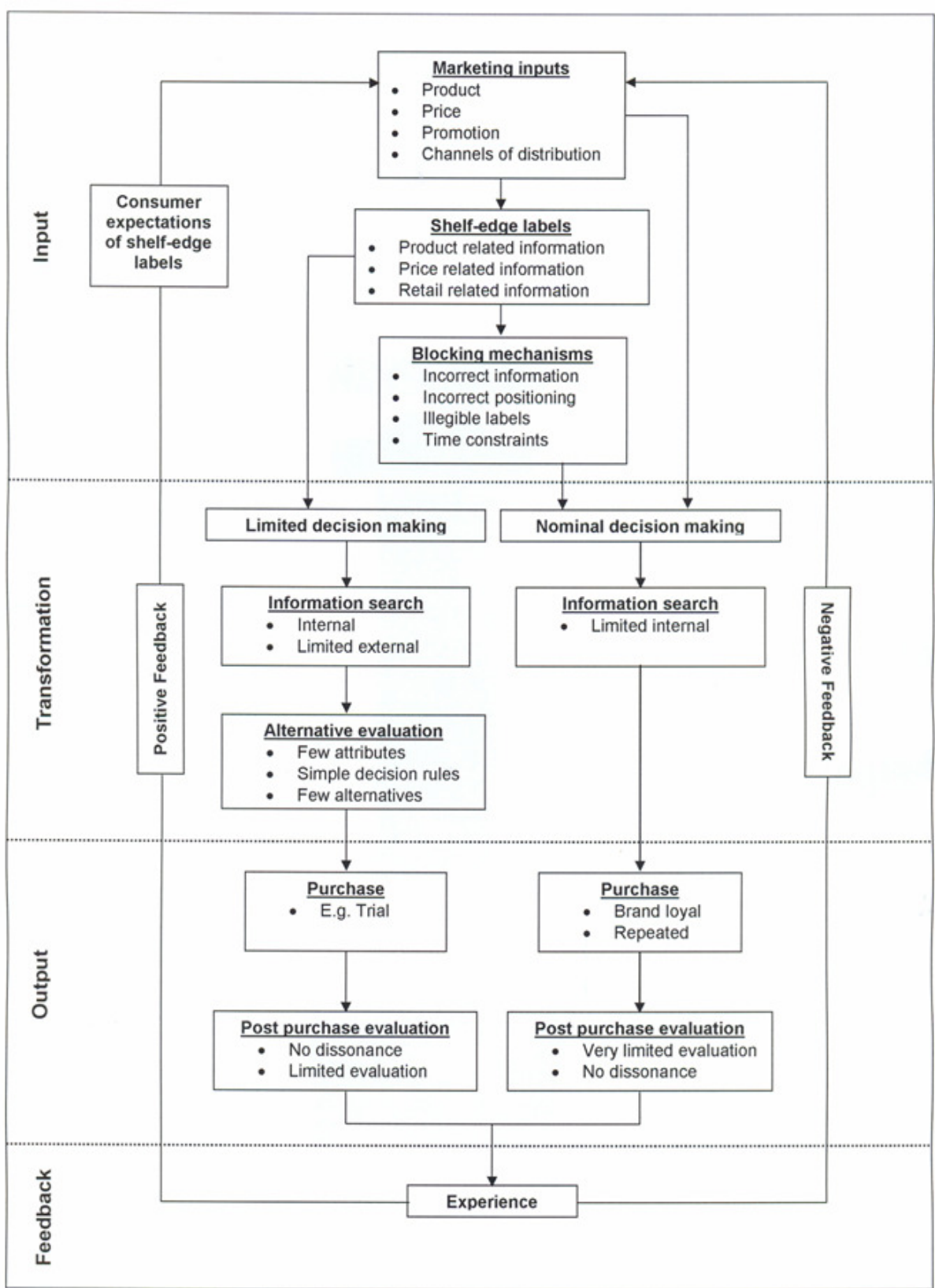

FIGURE 3: CONSUMERS' DECISION-MAKING PROCESSES 
Kanuk (2007:531), consumers are confronted with marketing inputs such as price, product, promotion and channels of distribution during the initial phases of their decision-making processes. To the limited decision-maker, shelf-edge labels offer informational input in terms of product (in considering purchasing a new product or switching brands), price (by comparing different products, stores and brands according to price) and retail-related information (such as shelf-life and out-of-stock occurrences). However, as illustrated in Figure 3, the input of such information may be counteracted by blocking mechanisms such as incorrect positioning of shelf-edge labels, illegible and incorrect labels as well as time, which is often limited during grocery shopping (Kahn \& McAlister, 1997:117). These circumstances may leave the consumer no option other than to engage in nominal decision-making.

Nominal decision-makers would transform less input during their acquisition of grocery items, and the value of shelf-edge labels as an external source of information input is circumscribed. Information is mostly derived internally from memory, and the decision to purchase is actively simplified (Cant et al, 2006:197). In this regard, the model of Hawkins et al (2007:511), which has been incorporated into Figure 3, clearly distinguishes the differences in transformation during limited and nominal decision-making. The concept of equifinality (Gregoire \& Spears, 2007:4; Whitchurch \& Constantine, 1993:334) is exemplified in that although input and transformation may differ in limited and nominal decision-making processes, the outputs remain the same: a purchase is made (whether it be trial, brand-loyal or repeated) and post-purchase evaluation is performed, and these accumulate into experience that is fed back into the system as feedback loops.

As illustrated in Figure 3, feedback loops may be either negative or positive. Negative feedback loops maintain homeostasis or initiate changes in the system to restore homeostasis, whereas positive feedback loops promote changes that would alter the system's homeostasis (Whitchurch \& Constantine, 1993:334). As pointed out by Marx and Erasmus (2006), if consumers are satisfied the possibility of repeat purchase behaviour is increased. This may include having certain expectations of the type of information input that can be derived from shelf-edge signage to guide decision-making processes. On the other hand, blocking mechanisms that inhibit the informational input of shelf-edge signage can be experienced so intensely that the consumer is not prepared to continue current behaviour and would, for example, visit another outlet, thus epitomising feedback loops.

Naturally various other internal and external influences apart from shelf-edge signage may impact on consumers' decision-making processes within a grocery store environment. The possibility of adding various other elements to the proposed conceptual frame thus exists. Notwithstanding its limitations, the framework could serve as a basis from which researchers may further extend knowledge in this specific consumer behaviour domain.

\section{CONCLUSION}

The findings of this study are restricted to a small subset in the Gauteng region and can therefore not be generalised to the larger South African consumer population. Despite its limitations, the study does provide some insight into the input of shelf-edge signage as an information source during consumers' decisionmaking processes when purchasing products in a grocery retail context. Retailers are interested in whether shelf-edge signage is of any informational value to consumers and consequently influence their decision-making behaviour when in the grocery store environment. The findings of this study prove that this would depend on the type of decision-making process the consumer is involved in, as consumers mostly revert to nominal or limited decision-making depending on the product category in question.

Evidently, shelf-edge signage is of value as an external source of information to the consumer who engages in limited decision-making, specifically with regard to the provision of product-, price- and retailrelated information when, for example, switching brands and trying new products. However, when grocery consumers revert to nominal decision-making, as in the case of brand-loyal or repeat purchases, the informational value of the signage diminishes as consumers predominantly rely on memory and habitual purchase reinforcement as well as their internal sources of information to guide their purchasing decisions. Retailers are encouraged to understand the importance of the nominal and limited decision-making processes of the consumer for various grocery categories if they are to drive sales through the shelf-edge signage system.

The study also provides some clarity about the problems consumers may incur in the use of shelf-edge signage, which act as blocking mechanisms in the decision-making processes. These blocking mechanisms included incorrect information on the shelf-edge signage, incorrect positioning of the signage, illegibility of the information on the signage and consumers' time constraints in searching for and interpreting the information. These aspects inhibit the extent to which shelf -edge labels succeed in communicating specific information to the consumer on which to build the purchase decision. Participants' responses also indicated that these mechanisms may have negative implications for the South African retailer as well as the manufacturer, especially in terms of sales and revenue which are lost.

Most of the blocking mechanisms identified are brought about by human error and can therefore be addressed in the retail sector. Consumers expect shelf -edge labels to assist them in their decision-making processes and therefore to carry an accurate barcode, unit price and description of the product and to be correctly placed with the product. The implementation of electronic shelf-edge labelling may prove beneficial in this regard, as it would enhance data integrity, information accuracy and secure positioning and could be updated with less effort. In their recommendations, 
participants emphasised the importance of correct positioning as well as accurate and legible information on shelf-edge signage. Although consumers seem satisfied with the type of information currently included on shelf-edge signage, retailers could further develop the informational value of shelf-edge signage by adding information pertaining to product ingredients and nutritional value. Yet participants underlined the fact that such recommendations would be subject to the retailer's ability to provide accurate descriptions on shelf-edge signage.

It should be emphasised that this study merely serves an exploratory and descriptive purpose. Although it succeeds in establishing some groundwork in identifying relevant ideas and concepts with regard to the phenomenon discussed, future research should include a quantitative study on shelf-edge signage and focus on a larger sample that could provide more representative data and possibly reflect the cultural dimensions that may impact on results. Attention could be given to more specific product categories. The significance of such research lies in the opportunities that retail can leverage to engage the grocery shopper at the point of purchase in order to drive purchases or stimulate consumer satisfaction. Manufacturers may also benefit from a shelf-edge signage study as it offers the opportunity to understand what drives purchases at the shelf and whether specific shelf-edge signage contributes to specific product category purchases, and if so, how.

\section{REFERENCES}

ACNIELSEN. 2002. Grocery universe. Johannesburg. Nielsen Media.

AUERBACH, CF \& SILVERSTEIN, LB. 2003. Qualitative data: an introduction to coding and analysis. New York. New York University Press.

BABBIE, E \& MOUTON, J. 2007. The practice of social research. South African edition. Cape Town. Oxford University Press.

BARBOUR, RS. 2001. Checklist for improving rigour in qualitative research: a case of the tail wagging the dog? Available online. URL: http:// bmj.bmjjournals.com.cgi/content/full/322/7294/1115. Accessed 19 July 2005.

BERGEN, M, LEVY, D, RAY, S, RURBIN, PH \& ZELIGER, B. 2004. When little things mean a lot: on the inefficiency of item pricing laws. Available online. URL: http://econwpa.wustl.edu:8089/epslle/ papers/0405/0405005.pdf.gz. Accessed 19 July 2005. BRONNEBERG, BJ \& VANHONACKER, WR. 1995. Limited choice sets, local price response, and implied measures of price competition. Journal of Marketing Research 33(May):163-173.

BURGESS, SM. 1998. The new marketing: building strong marketing strategies in South Africa today. Durban. Zebra Press.

CANT, MC, BRINK, A \& BRIJBALL, S. 2006. Consumer behaviour. Cape Town. Juta.

CHANDRASEKHARAN, S. 2004. Epistemic structure: how agents change the world for cognitive congeniality. Available online. URL: http://www.carleton.ca/iis/
TechReposts/files/2004-03.pdf. Accessed 26 April 2005.

COMPETITION BUREAU. 2005. Be a smart shopper: make sure you pay the right price. Available online. URL: http://www.competitionbureau.gc.ca.internet/ index.cfm?itemID=12198/g=e. Accessed 10 February 2005.

DELPORT, CSL \& FOUCHé, CB. 2005. The place of theory and the literature review in the qualitative approach to research. In De Vos, AS, Strydom, H, Fouché, CB \& Delport, CSL. 2005. Research at grass roots for the social sciences and human service professions. 3rd ed. Pretoria. Van Schaik.

DE VOS, AS. 2005. Qualitative data analysis and interpretation. In De Vos, AS, Strydom, H, Fouché, CB \& Delport, CSL. 2005. Research at grass roots for the social sciences and human service professions. 3rd ed. Pretoria. Van Schaik.

DIAMOND, WD \& JOHNSON, RJ. 1990. The framing of sales promotions: an approach to classification. Advances in Consumer Research 17:494-500. Available online. URL: http://forum.gfk.ru/texts/articles/fsp/ pdf. Accessed 15 March 2005.

DICKSON, PR \& SAWYER, AG. 1990. The price knowledge and search of supermarket shoppers. Journal of Marketing 54(July):42-53.

DONOGHUE, S. 2000. Projective techniques in consumer research. Journal of Family Ecology and Consumer Sciences 28:47-53.

DU PLESSIS, PJ \& ROUSSEAU, GG. 2007. Buyer behaviour: understanding consumer psychology and marketing. $3^{\text {rd }}$ ed. Cape Town. Oxford University Press.

ERASMUS, AC, BOSHOFF, E \& ROUSSEAU, GG. 2001. Consumer decision-making models within the discipline of consumer science: a critical approach. Journal of Family Ecology and Consumer Sciences 29:82-90.

Food Marketing Institute. 2001. Shelf price accuracy in supermarkets that scan. Available online. URL: http:// www.fmi.org.2001. Accessed 15 March 2005.

FOX, B. 2002. Electronic shelf draw net interest as price fall. Available online. URL: http://www.stores.org. Accessed 26 April 2005.

Fujitsu. 2005. Electronic shelf labels hit South Africa. Available online. URL: http://www.fujitsu.com/za/. Accessed 15 March 2005.

GREEFF, M. 2005. Information collection: interviewing. In De Vos, AS, Strydom, H, Fouché, CB \& Delport, CSL. 2005. Research at grass roots for the social sciences and human service professions. 3rd ed. Pretoria. Van Schaik.

GREGOIRE, MB \& SPEARS, MC. 2007. Foodservice organizations: a managerial and systems approach. $6^{\text {th }}$ ed. Upper Saddle River, New Jersey. Pearson Prentice Hall.

HAWKINS, DI, MOTHERSBAUGH, DL \& BEST, RJ. 2007. Consumer behavior: building marketing strategy. $10^{\text {th }}$ ed. Boston. McGraw-Hill Irwin.

HAYES, N. 2000. Doing psychological research: gathering and analysing data. Buckingham. Open University Press.

HENNING, E, VAN RENSBURG, W \& SMIT, B. 2004.

Finding your way in qualitative research. Pretoria. Van Schaik. 
HIGGENSOM CS, RAYNER, MJ, DRAPER, E \& KIRK, TR. 2002. How do consumers use nutrition label information? Available online. URL: http:// www.ingentaconnect.com/search/expand? pub=infobike://mcb/017/2002/00000032/00000004/ art00003\&unc $=$. Accessed 15 March 2005.

HOEPFL, MC. 1997. Choosing qualitative research: a premier for technology education researchers. Journal of Technology Education 9(Fall):47-63.

HUI, B. 2004. Express your brand at POS to win hearts of fickle consumers. Media Asia (Dec):12.

INMAN, J, MCALISTER, L \& HOYER, WD. 1990. Promotion signal: proxy of a price cut? Journal of Consumer Research 17(June):74-81.

IRIS, IM. 2002. In-store impact on impulse shoppers. Marketing (UK) (Jan):27-28.

JANSSON, C, BOINTON, B \& MARLOW, N. 2003. An exploratory conjoint analysis study of consumers' aesthetic responses of point-of-purchase materials. International Review of Retail Distribution and Consumer Research 13(Jan):59-76.

KAHNAMAN, D \& TVERSKY, A. 1973. On the psychology of prediction. Psychological review 80(4):237251.

KAHN, BE \& MCALISTER, L. 1997. Grocery revolution: the new focus on the consumer. Massachusetts. Addison Wesley Educational Publishers.

KELLY, JP, SCOTT, MS \& HUNT, HK. 2000. Fulfilment of planned and unplanned purchase of sale- and regular-price items: a benchmark study. International Review of Retail, Distribution and Consumer Research 10 (July):247-263.

KREFTING, L. 1991. Rigor in qualitative research: the assessment of trustworthiness. The American Journal of Occupational Therapy 45(3):214-222.

LINCOLN, YS \& GUBA, EG. 1985. Naturalistic enquiry. London. Sage.

MANNING, KC, SPROTT, D \& MIYAZAKI, AD. 2003.

Unit price usage knowledge: conceptualization and empirical assessment. Journal of Business Research 56:367-377.

MARTINS, JH. 2006. Household cash expenditure by living standards measure group. Journal of Family Ecology and Consumer Sciences 34:1-31

MARX, NJMM \& ERASMUS, AC. 2006. An evaluation of the customer service in supermarkets in Pretoria East, Tshwane Metropolis, South Africa. Journal of Family Ecology and Consumer Sciences 34:56-68. MASON, J. 1996. Qualitative researching. London. Sage.

MAYKUT, P \& MOREHOUSE, R. 1994. Beginning qualitative research: a philosophic and practical guide. London. The Falmer Press.

MAYS, N \& POPE, C. 2000. Education and debate: qualitative research in health care assessing quality in qualitative research. Available online. URL: http:// bmjjournals.com/cgi/content/full/320/7226/50. Accessed 27 July 2005.

MIYAZAKI, AD, SPROTT, DE \& MANNING, KC. 2000. Unit price on retail shelf label: an assessment of information prominence. Journal of Retailing 76(1):93112.

MOON, S \& RUSSEL, GJ. 2002. Profiling the reference price consumer. Available online. URL: http:// w w w. bi z. u i o w a . ed u/m r kt g/pdf/ reference_price_consumer.pdf Oct. Accessed 17 February $200 \overline{5}$.

MURPHY, D. 2003. Taking ads to the shop floor. Marketing (UK) (8 July):23

NEAL, C, QUESTER, P \& HAWKINS, D. 2006. Consumer behaviour: implications for marketing strategy. Boston. McGraw-Hill.

NUCIFORA, A. 1995. The point of point-of-purchase. Northern New Jersey Business 3(15):21.

PIEMONTE, T. 2001. The perfect store. Automotive Marketing (Jan):14-20.

SCHIFFMAN, LG \& KANUK, LL. 2007. Consumer behaviour. $9^{\text {th }}$ ed. Upper Saddle River, New Jersey. Prentice Hall.

SPEARS, MC. 2004. Systems approach to a foodservice organization. $5^{\text {th }}$ ed. Englewood Cliffs, New Jersey. Pearson Prentice Hall.

STEWART, DW \& SHAMDASANI, PN. 1990. Focus groups: theory and practice. London. Sage.

STRYDOM, H. 2005. The pilot study. In De Vos, AS, Strydom, H, Fouché, CB \& Delport, CSL. 2005. Research at grass roots for the social sciences and human service professions. 3rd ed. Pretoria. Van Schaik. STRYDOM, H \& DELPORT, CSL. 2005. Sampling and pilot study in qualitative research. In De Vos, AS, Strydom, H, Fouché, CB \& Delport, CSL. 2005. Research at grass roots for the social sciences and human service professions. 3rd ed. Pretoria. Van Schaik. TAGNETICS. 2004. Powerful shelf management system: expanded functionality delivers fast payback and its "future safe". Available online. URL: http:// www.tagnetigs.com. Accessed 15 March 2005.

TSIROS, M \& HEILMAN, CM. 2004. The effect of expiration dates on the purchasing behavior for grocery store perishables. Available online. URL: http:// www.commerce.virginia.edu/faculty_research/ Research/Papers/Heilman Perishable ThirdRound.pdf. Accessed 10 February 2005.

URBANY, JE, DICKSON, PR \& KALAPURAKAL, R. 1996. Price search in the retail grocery market. Journal of Marketing 60(April):91-104.

VANHUELE, M \& DREZE, X. 2000. Do consumers really know if the price is right? Direct measures of reference price and their implications for retailing. Available online. URL: http://www.hec.fr/hec/fr/ professeur_recherche/cahier/marketing/CR711.pdf. Accessed 10 February 2005.

WEBB, W. 2002. How it works; on the shelf electronic price labels. EDN. Available online. URL: www.edn.com. Accessed 26 April 2005.

WHITCHURCH, GG \& CONSTANTINE, LL. 1993. Systems theory. Sourcebook of family theories and methods: a contextual approach. New York. Plenum Press. 